УДК: 330.3:616-036.21(497.16)

DOI: https://doi.org/10.18485/fb_covid19.2020.ch8

\title{
УТИЦАЈ КОВИДА 19 НА ЕКОНОМИЈУ ЦРНЕ ГОРЕ
}

\author{
др Саша Зејак ${ }^{l}$
}

Апстракт: Анализа утицаја пандемије изазване вирусом ковид 19 на економију Црне Горе, коју је Свјетска здравствена организација (С30) прогласила 11. марта 2020. године, од непроцјењивог је значаја у условима растућих безбједносних ризика, на које већина држава у свијету нема адекватну стратегију одбране односно: превентиве, активног дјеловања и ублажавања последица пандемије. Економија Црна Горе, као и већина економија у свијету, није била у потпуности припремљена за функционисање у условима пандемије, због чијих последица не може бити спремна да се суочи са сличним проблемом у ближој будућности уколико се не промијени друштвени приступ према израженим пандемијским ризицима. У том контексту антиципирање догађаја на основу претрпљеног искуства „што те мучи - то те учи", чије последице и дио решења су представљени у овом раду, пружају солидну основу за дубинско сагледавање овог проблема, његов утицај на економију и могуће механизме заштите - кроз сталност процеса њеног усавршавања. Сваки економски систем који жели да опстаје мора имати одређене способности (квалитете) опстајања. Један од предложених квалитета у овом раду јесте и обавезна имплементација система менаџмента континуитетом пословања, већи уплив академских знања у владиним стручним тијелима, као и формирање трајног националног тијела које би се бавило превентивом, активним дјеловањем и ублажавањем последица пандемија на економију Црне Горе. Благовремене, смјеле и пажљиво осмишљене мјере ублажавања стресних ситуација могу значајно ограничити друштвени и економски утицај кризе изазване пандемијом.

Кључне ријечи: економија, пандемија, ковид 19, ризик, безбједност.

${ }^{1}$ Европски центар за мир и развој Универзитета за мир Уједињених нација, Београд; еmail: szejak@t-com.me 


\section{УВОД}

„Црна Гора је мала, отворена економија. Такође је економија која је посебно рањива на спољне шокове, јер се у великој мери ослања на прилив капитала из иностранства како би стимулисала свој раст"

Анализа било којег система и његове интеракције са факторима од утицаја зависи од квалитета и дубине њиховог познавања. У том контексту неопходно је дати полазне дефиниције економије као система и пандемије као једног од најзначајнијих фактора који утичу на тај систем.

Појам економије је препознат и прије нове ере и представља кованицу грчког

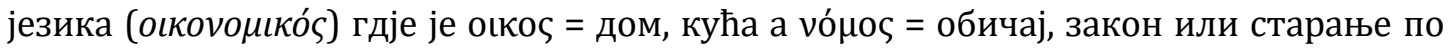
закону. Касније овај термин се појављује као религијски термин, који је остао записан на више мјеста у Новом завјету (као Божија економија = Божије управљање свијетом). Најадекватнији превод на српски језик би био „домострој“, односно устројавање дома или ти домаћинства, при чему је економ (а не економиста) онај који се бринуо о правилном устројству дома. Звање економа је и сада задржано у православним српским манастирима као тековина прошлости. Економија данас представља једну свјетовну науку која се бави управљањем (газдовањем, устројством, распоређивањем) материјалних и нематеријалних добара.

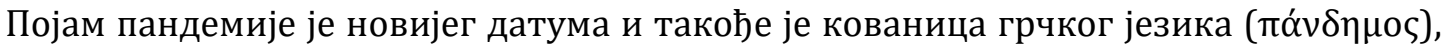

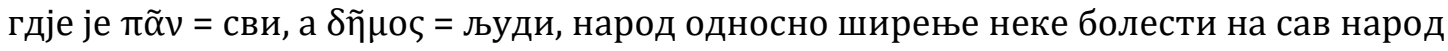
- у овом случају на глобалном свјетском нивоу.

Свакако, из оба појма може се закључити да се односе на човјека и на његов битисање, те се може говорити и о томе да устројавање своје куће (економисање) мора узети у обзир епидемиолошки, односно пандемијски фактор који је често у историји био главни узрочник пустошења домаћинстава. У том контексту треба посматрати и индивидуалне домаћинске економије, националне и свјетску економију - у непрекидној интеракцији човјека и његовог окружења. Конкретније, економија и економисање на сваком нивоу мора да има „резервни положај“, односно „план б“ или чак више њих. У овом понашању по мишљењу аутора овог рада највиша достигнућа су учињена у домену сигурносних државних института, од којих ове фразе и происходе (нпр. војска, безбедносне службе), чија искуства треба примијенити на економске субјекте у дијелу у којем је то могуће.

Једна од специфичности која је везана за Црну Гору и ближе окружење јесте и та да постоји велики јаз између владиних чиновника и високообразовних институција, које су по мишљењу аутора овог рада недовољно укључене током читавог периода пандемије. Велики број значајних истраживања, података и препорука свјетских ауторитета, на основу којих се доносе значајне државне одлуке, завршава у Владиним канцеларијама, у привременим и струковним удружењима, без даљих консултација од стране академских експерата за међународну и регионалну економију и пандемију. Јасно је да ове институције имају једну од одлучујућих улога у санирању последица пандемије, али исто тако оне нипошто не могу бити

\footnotetext{
2 „The World Bank in Montenegro", The World Bank, https://www.worldbank.org/en/country/montenegro 20/08/2020
} 
супститути академских центара, будући да се ради о глобалном проблему, за који је потребно најмање више десетина специјализованих знања.

Оно што је у управљању ризицима од посебног значаја јесте да тзв. помак у препознавању (recognition lag), односно период између тренутка у коме се јавља потенцијално дестабилизирајући поремећај и тренутка у коме је он препознат буде довољно кратак, како би креатори економске политике могли успјешно да управљају њиме. Стога је овај рад намијењен ширем кругу интересената, прије свега онима који желе да се упознају са актуелним економским трендовима, који желе да покрену или да осавремене свој приступ бизнису, као и онима другима побуђенима интелектуалном радозналошћу.

Неформални комуникациони канали унутар система могу довести до цурења информација или пак пласирања дезинформација, избјегавању одговорности која није документована, чиме се доприноси конфузији и изостајању акције у потребном времену. Као примјер неформалних комуникационих канала који су довели до нежељених последица који могу резултирати приватним тужбама и ширењем панике у широј заједници јесте и списак заражених од ковида 19, када је службеник Дома здравља Подгорица ухапшен због сумње да је објавио списак података обољелих у Подгорици од ковида 19, прослеђујући податке колегама са истим или мањим овлашћењима ${ }^{3}$. На овај начин, пошто није успостављен ВСМ, а услед неприлагођености особља и технологије новонасталој ситуацији, менаџмент није успио да заштити репутацију и имиџ ове установе у потпуности, без обзира на уложене напоре запослених у борби са ковидом 19.

Недостатак менаџерске обуке је недостатак система који се среће у мање демократским друштвима у којима се на кључним улогама у системима постављају лица по политичкој, националној или вјерској припадности, без професионалних и стручних компетенција. Овај проблем је посебно изражен на оним нивоима власти који трпе чешће промјене, као нпр. локална власт, која се у Црној Гори више мијења него државна власт, тако да кључни менаџери (чак иако дођу са дијелом потребних компетенција) немају времена да се прилагоде системима, да их упознају и да их усавршавају. Немогуће је стећи и задржати повјерење у способност таквог менаџмента система у борби са кризним ситуацијама. Свако дјеловање на свијету, без обзира на његову природу, мора показати еластичност на дуги рок, иначе ће нестати. При томе је евидентно да менаџерска континуирана обука, као карактеристика развијених друштава и система представља неопходан услов опстанка система, односно организација.

Систем менаџмента континуитетом пословања настоји да предвиди и проактивно дјелује на узрочнике стресова, те да увијек има одговор на све могуће изазове, без обзира на њихову тежину и комплексност. Као једном успостављен, примјењивани стандард, он временом постаје све интелигентнији, како систем препознаје своје слабости до оне мјере у којој може да функционише „у свим претпостављеним ситуацијама“. Ова препознатљивост ситуација односно

3 Јелена Јовановић, „Ухапшен службеник Дома здравља Подгорица: Прослиједио списак обољелих преко вајбера?“, Вијести, 7. април 2020, доступно на: https://www.vijesti.me/vijesti/crna-hronika/uhapsen-osumnjiceni-za-objavljivanje-spiskaoboljelih, 20/08/2020. 
поремећаја са којима се може суочити систем, односно организација описује се кроз искуствено изграђену стратегијску и операциону матрицу коју ВСМ претпоставља као основну проактивну мјеру у спречавању прекида пословања у нежељеним ситуацијама.

Дугорочно, сваки неадекватан приступ изазовима у обављању дјелатности негативно утиче на новчане токове, па самим тим и на пад вриједности организација, гледано кроз вриједности удјела или власничких хартија од вриједности односно на благостање уже или шире друштвене заједнице. Овај утицај је опасан по окружење, без обзира да ли се ради о пословним субјектима, државним органима или невладиним организацијама, сходно њиховој улози, односно значају у националним или глобалним оквирима. Овим се отвара и низ других питања: враћање повјерења и вриједности након инцидентних ситуација, са свим комплексностима које оно са собом носи, ако је уопште могуће повратити повјерење, односно вриједност. Свакако, хтио то систем или не, односно, без обзира на интерне системске наклоности према ВСМ, екстерни покретачи континуитета у пословању су претежно екстерног карактера, различитих интереса и утицаја на систем, али се сваки од тих интереса или утицаја своди на потребу обавезности континуитета обављања дјелатности на кратки и дуги рок.

Ови покретачи захтијевају да се систем бави елементима интегрисаног управљања у ванредним ситуацијама, обезбјеђујући континуитет пословања путем следећег тока: предвиђање, процјена, превенција и припрема. У том контексту јако је важно препознавање нових безбједносних изазова и ризика и процјена њихових могућих посљедица по пословање, људске и материјалне ресурсе. Епидемије и пандемије, без обзира да ли настају природним путем или су вјештачки изазване, што је данас такође реално и могуће, с обзиром на степен развоја и злоупотребе науке, у том контексту сагледавају се као један од водећих безбједносних ризика и изазова, а микроорганизми који до њих доводе могу се сагледавати као пријетња и кроз призму биолошког тероризма и ратовања, климатских промјена, миграција. Ову претњу водеће земље света и међународне организације колективне безбједности већ су уврстиле на листу значајних потенцијалних ризика. Кризни менаџмент и кризна комуникација уз адекватну и перманентну припрему ресурса су у том погледу изузетно значајни за ефикасан и квалитетан одговор, али и превенцију.

\section{Садашњи покретачи економских активности и њихов однос према безбједносним ризицима}

\section{Државни и локални органи и службе за кризне ситуације}

Civil Contingencies Act Enhancement Programme у Великој Британији захтијева да локална и државна тијела за хитне и ванредне ситуације имају имплементиран ВСМ стандард, будући да овај стандард омогућава ефикасније и ефективније дјеловање у хитним ситуацијама од интереса за ужу или ширу заједницу, које требају подржати све институције и организације како би се повећала еластичност свих субјеката од значаја за реаговање у кризним ситуацијама.

НКТ (Национално координационо тијело за заразне болести у Црној Гори) је током периода пандемије често дјеловало нејасно, стихијски, без довољно детаљних упутстава о мјерама које је уводило и образложења истих, што се може 
дјелимично образложити непознавањем потпуног карактера пандемије и њеног узрочника, али постоји дио јавности који сматра да је ово тијело често употребљавано и за сврхе за које није било предвиђено. Црна Гора би требало у најскоријем року да дефинише број сталних чланова НКТ, њихове специјалности и орган који би вршио надзор, односно ревизију поступања НКТ. У том дијелу аутор овог рада предлаже формирање сталног тијела, а не привременог, које би континуирано пратило и дјеловало на пандемијске и друге ризике, које би имало пододборе за све гране економије - онако како то чини Привредна комора Црне Горе.

У том контексту посебно је важно по завршетку пандемије објективно и мулти секторски анализирати научене лекције, уочене слабости, као и позитивна и негативна искуства осталих држава и актера у региону и свијету, са циљем да се у будућности на сличне изазове, којих ће несумњиво бити, реагује још одлучније, са што мање штетних посљедица по друштво и систем у цјелини, од људског здравља до економије. С тим у вези, сваку кризу треба посматрати и као развојну шансу, а регионалном сарадњом и повезивањем би се тај одговор могао учинити још ефикаснијим и посљедице кризе би свакако биле значајно мање.

На тај начин омогућиле би се превентивне и текуће мјере безбједности на свим нивоима. Као примјер повећања или давања овлашћења одређеном државном тијелу може се навести следеће:,Израелски премијер Бењамин Нетањаху недавно је овластио Израелску безбједносну агенцију да користи технологију надзора која је нормално ограничена на борбу против терориста како би пратила пацијенте са коронавирусом“4, што може бити од користи, али отвара и Пандорину кутију могућих злоупотреба у циљу ограничавања слободе појединца. Искуство показује да су након сваке кризе појачавани контролни и репресивни механизми (примјер: антраксна кампања у САД 2001).

\section{Осигуравајућа друштва}

Осигуравајућа друштва, као могући директни оштећени у дисконтинуитету пословања осигураника, све више траже имплементацију ВСМ стандарда као један од начина на који могу смањити ризике који се односе на ову врсту ризика. Тачније, системи, тј. организације, увођењем ВСМ стандарда и његовим одржавањем и усавршавањем утичу на квалитет повјерења према осигуравајућим друштвима користећи бенефите осигурања у ситуацијама када осигуравајуће куће оцијене да су изложене мањим ризицима осигурања.

Током периода пандемије све осигуравајуће куће у Црној Гори су практично замрзнуле дјелатност у појединим врстама осигурања, што убудуће мора бити ријешено на начин да се тржиште самостално развија, али да се спријечи монополски наступ осигуравајућих кућа које у условима пандемије скоро истовјетно мијењају услове пословања, односно не врше дјелатност на уобичајено квалитетан начин.

4 Јувал Ноа Харари, „Свијет након коронавируса“, Вијести, 23. март 2020, доступно на: https://www.vijesti.me/svijet/globus/426884/svijet-nakon-koronavirusa, 21/08/2020. 


\section{Интерна системска контрола}

Интерна системска контрола која прати токове и правила која прописују и захтијевају одређена тржишта и начини пословања (нпр. берзе) добијају све више на значају као дио обавезне савремене коропоративне културе, која подразумијева највећи степен усаглашености са захтјевима тржишта. Како су ови захтјеви све више усаглашени са ВСМ стандардом, евидентна је обавезност његове имплементације.

Интерне системске контроле у Црној Гори у условима пандемије практично не функционишу из два разлога: или не постоје или нијесу спремне да се суоче са безбједносним ризицима. Свакако, у овом контексту не треба посматрати војнобезбједносне и друге службе, чија искуства треба примијенити и на друге субјекте, будући да по природи ствари ове службе врше сталне пројекције ризика и представљају посљедњу линију отпора пред безбједносним ризицима.

\section{Екстерни ревизори}

Екстерни ревизори који контролишу имплементирани ВСМ стандард јесу једна од најглавнијих карика холистичког приступа који подразумијева ВСМ стандард, будући да од квалитета њихове оцјене спровођења ВСМ стандарда зависи квалитет реаговања у инцидентним ситуацијама и новчани и неновчани губици система и окружења.

Црна Гора у својим агендама није препознала ВСМ стандард, те постоји врло мали број појединаца (најчешће из безбједносних служби) који су обучени да буду имплементатори или екстерни ВСМ ревизори. Како је човјечије знање пресудни фактор у развоју свијета, није неопходно истицати даљи значај едукације, без обзира на то да ли ће ВСМ стандард бити обавезан у ближој будућности у Црној Гори као што је то нпр. у Великој Британији.

\section{Добављачи и купци (ланац снабдијевања)}

Ниједна организација није сама себи довољна у толикој мјери да не зависи од једног или више кључних добављача производа или услуга. Овим кључни добављачи постају заинтересовани за нпр. дистрибуцију својих производа или вршење услуга на начин на који се смањује притисак на ланац купаца у ванредним ситуацијама, посебно онда када се захтијева да систем који користи или даље дистрибуира производе добављача крајњим купцима не дозволи пад тржишног учешћа или је у нарочито преузетој обавези да исто изврши. Са своје стране купци исто тако траже стабилност снабдијевања и додатну обавезу добављачима која се огледа у сталности испоруке. Опасности које су препознате као узроци пораста ризика у ланцима снабдијевања су нпр.: аутсорсинг, који може да представља више фактора од уситњености процеса производње те самим тим и аутсорсинга, смањења броја добављача у ситуацији глобалног тржишта, варијабилност у тражњи производа (нпр. заштитне маске у вријеме пандемије), те недостатак потпуне видљивости и контроле ланца снабдијевања у којој он може бити прекинут на различите начине од било којег учесника у ланцу снабдијевања. Значи и купци и добављачи потребују имплементиран ВСМ стандард будући да тржиште намеће све мању лојалност међу купцима и добављачима. 
Ланац снабдијевања у Црној Гори у вријеме пандемије углавном није прекинут, али је био евидентан дефицит алтернативних купаца и добављача, посебно у дијелу фармацеутике, резервних дјелова и набавке опреме која компензира утицај пандемије.

\section{Будући покретачи економских активности и њихов однос према безбједносним ризицима}

\section{Инвеститори}

Инвеститори су онај фактор пословања који обезбјеђују средства којима се реализују пословни планови и планови дјеловања који су посебно заинтересовани за исплативост инвестиција, било да се исплативост исказује новчано или на неки други начин. Како се инвестициони ризик смањује увјерљивошћу имплементираног ВСМ стандарда, логично је да инвеститори траже свођење инвестиционог ризика до најнижег могућег, чак до скоро нултог нивоа. Ово је један од разлога мањих инвестиција у системе који немају имплементиран ВСМ стандард.

У Црној Гори у критичним дјелатностима (туризам, металопрерада, енергетика) не постоји имплементиран ВСМ стандард, што ствара несигурност инвеститорима и дјелује дестимулишуће на оне инвеститоре који започну дио инвестиција, а потом их селе на територије које им гарантују већу сигурност у инвестирању и пословању.

\section{Банке и друге финансијске организације}

Као и инвеститори, банке и друге финансијске организације имају исте разлоге којима се руководе приликом пласирања својих средстава. У Црној Гори су прије пандемијског таласа двије банке отишле у стечај, док су друге банке дале компензаторне мјере према грађанству и привреди на начин да су привремено одложиле враћање рата из кредитних задужења, али су задржале право наплате затезних камата у одложеном периоду, чиме су више ишле на своју корист него у корист грађана и привреде, јер су фактички пласирале постојеће кредите на дужи период са већим каматама, док су биле уздржане у новим кредитирањима.

\section{ИНДИКАТОРИ ПАДА ЕКОНОМСКЕ АКТИВНОСТИ УСЛЕД ПАНДЕМИЈЕ УЗРОКОВАНЕ КОВИДОМ 19}

Неупитно је да је Црне Гора, као и друге земље, ушла у рецесију и да има негативан економски раст због утицаја пандемије ковида 19. Даљи економски ток углавном зависи од даљег пандемијског тока, те се не може са сигурношћу утврдити крајњи негативан биланс пандемије, али се могу дати временски пресјеци и у њима утврђена стања која се могу упоређивати са периодима претходних година или са периодима који су били непосредно прије избијања пандемије. Дакле, интензитет рецесије је директно зависан од интензитета и дужине пандемије, као и од адекватне реакције државе, након чега би било реално очекивати економски опоравак и раст. 
Свакако, продубљивање рецесије у Европској унији и у окружењу је исто један од фактора који директно може утицати на економију Црне Горе. Интерне слабости црногорске економије које је чине нестабилном приликом екстерних шокова су следећи:

- као мала и отворена економија, нема широк спектар производње, већ се највише базира на конкурентност у туризму.

- Црна Гора у контексту туризма врши све већи притисак на природу и животну средину.

- као све мале државе она има већу државну управу него што то пропорционално имају веће државе, чиме се повећава ова врста расхода у бруто друштвеном производу Црне Горе.

- недовољно развијен финансијски сектор и недовољно инкорпориран у привреду и домаћинства.

- ограничења у монетарној политици која се односе на коришћење еура као средства плаћања.

- слободна и отворена трговина у којој развијени монополи доминирају и нарушавају равнотежу увоза и извоза, тј. постоји опасност од шокова везаних за односе размјене.

У складу са тим, ММФ5 је дао прогнозу кретања БДП6-а Црне Горе у 2020. години у односу на стопу инфлације и просјечне потрошачке цијене ${ }^{7}$, што је приказано на графикону.

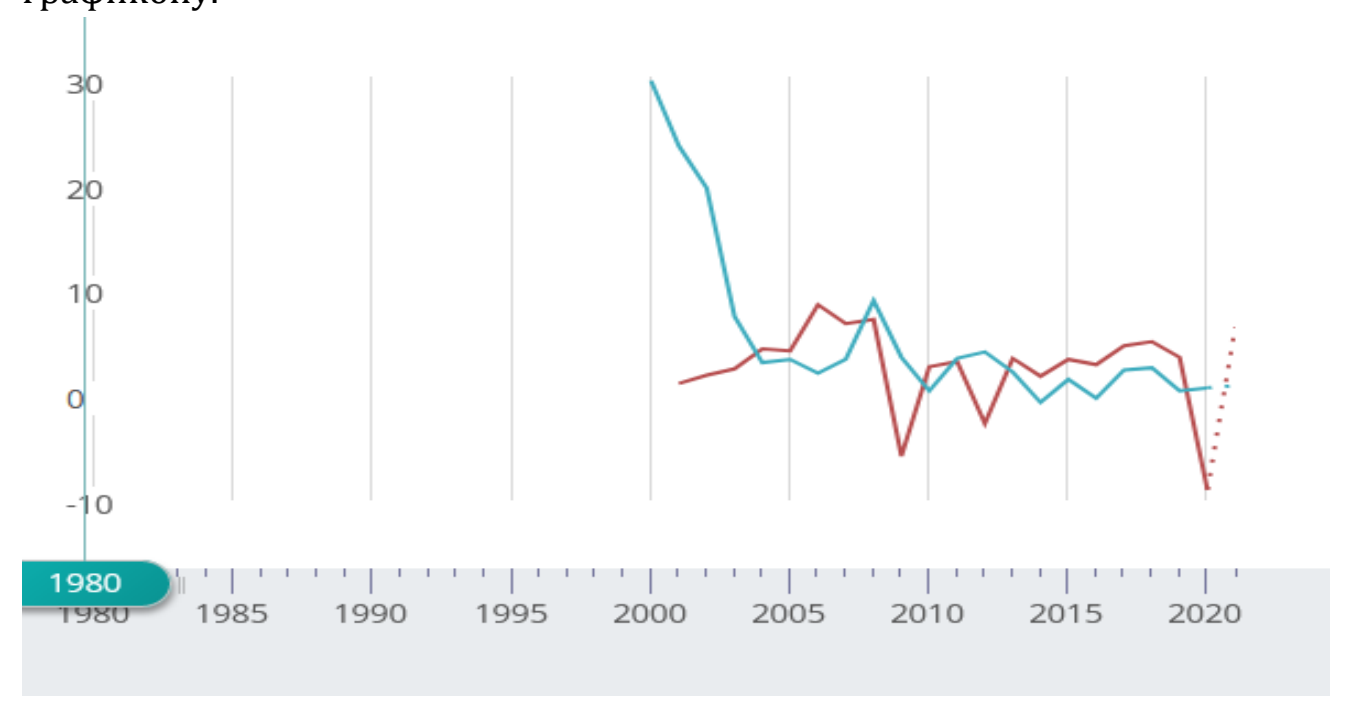

5 „Montenegro“, International Monetary Fund, available at: https://www.imf.org/en/Countries/MNE, 22/08/2020.

6 Бруто домаћи производ је најчешће коришћена појединачна мјера укупне економске активности земље. Представља укупну вриједност у сталним цијенама финалне робе и услуга произведених у некој земљи током одређеног временског периода, попут једне године.

7 Индекс просјечне потрошачке цијене (ЦПИ) је мерило просјечног нивоа цијена у земљи заснованог на цијени типичне потрошачке робе и услуга у датом периоду. Стопа инфлације представља процентуалну промјену у просјечном ЦПИ. 
- Пројектовани реални бруто друштвени производ: - 0.9\%

- Пројектовани раст потрошачких цијена: + 0,7\%.

Из тога је евидентно да ће пројектовани ток утицаја пандемије на БДП трајати најмање до краја 2020. године (уколико не наступи други талас пандемије или неки сличан економски стрес) и глобална економска рецесија.

Нешто позитивнији став који се тиче смањења економске активности Црне Горе дат је у очекивањима Европске комисије, у којем је наведено да ће се црногорска економија у 2020. години смањити за $5,9 \%{ }^{8}$ због негативних ефеката епидемије коронавируса, будући да је економија Црне Горе претежно заснована на туризму, који је најзначајнији фактор раста БДП-а.

Без обзира на коју се прогнозу БДП-а се ослонили, евидентан је драстичан пад економске активности Црне Горе у односу на позитиван тренд који је био прије пандемије ковида 19. Овај позитиван тренд најбоље се огледа у томе да је стопа реалног раста БДП-а у периоду прије пандемије - у I кварталу 2020. године износила $2.7 \%$. Из ових података се види како је фактички за мјесец дана (април мјесец) дошло до убрзане рецесије у Црној Гори.

\section{Утицај пандемије на пословне субјекте из области трговине на мало}

Циљ мјесечног истраживања трговине на мало је да обезбиједи податке о промету робе. Добијени подаци се користе за праћење обима и динамике кретања промета, анализу обима и промјена у структури личне потрошње, анализу сезонских карактеристика потрошње и сагледавање укупних економских кретања. ${ }^{9}$

\begin{tabular}{|c|c|c|c|c|c|c|}
\hline \multirow{3}{*}{ мјесец } & \multirow{3}{*}{$\begin{array}{c}\text { индекс } \\
\text { нивоа, } \\
2015=100\end{array}$} & \multicolumn{4}{|c|}{ стопа промета у трговини на мало, \% } & \multirow{3}{*}{ квартал } \\
\hline & & \multirow{2}{*}{$\begin{array}{c}\text { мјесечна } \\
\text { стопа, } \\
\text { м/м-1 }\end{array}$} & \multirow{2}{*}{$\begin{array}{c}\text { годишња } \\
\text { стопа, } \\
\text { м/м-12 }\end{array}$} & \multicolumn{2}{|c|}{$\begin{array}{c}\text { квартална } \\
\text { стопа }\end{array}$} & \\
\hline & & & & $q / q-1$ & $q / q-4$ & \\
\hline Апр-17 & 96.9 & $3.7 \%$ & $4.9 \%$ & \multirow{3}{*}{$21.0 \%$} & \multirow{3}{*}{$5.0 \%$} & \multirow{4}{*}{ II 2017} \\
\hline $\begin{array}{l}\text { May- } \\
17\end{array}$ & 102.9 & $6.2 \%$ & $5.2 \%$ & & & \\
\hline Јун-17 & 113.7 & $10.5 \%$ & $4.9 \%$ & & & \\
\hline Јул-17 & 134.3 & $18.1 \%$ & $4.7 \%$ & \multirow{2}{*}{$32.5 \%$} & \multirow{2}{*}{$5.0 \%$} & \\
\hline Авг-17 & 152.3 & $13.5 \%$ & $5.0 \%$ & & & III 2017 \\
\hline
\end{tabular}

8 Radomir Ralev, „EC expects Montenegro's GDP to contract 5.9\% in 2020“, SeeNews, 6 $6^{\text {th }}$ May 2020, available at: https://seenews.com/news/ec-expects-montenegros-gdp-to-contract-59in-2020-697818 23/08/2020.

9 „Методолошко упутство: Статистика мјесечне трговине на мало (2012)“, Завод за статистику Црне Горе, Подгорица, јануар 2012, доступно на: https://www.monstat.org/userfiles/file/trgovina/2014/Metodologija\%20trgovine\%20na\%2 0malo.pdf 


\begin{tabular}{|c|c|c|c|c|c|c|}
\hline \multirow{3}{*}{ мјесец } & \multirow{3}{*}{$\begin{array}{c}\text { индекс } \\
\text { нивоа, } \\
2015=100\end{array}$} & \multicolumn{4}{|c|}{ стопа промета у трговини на мало, \% } & \multirow{3}{*}{ квартал } \\
\hline & & \multirow{2}{*}{$\begin{array}{c}\text { мјесечна } \\
\text { стопа, } \\
\text { м/м-1 }\end{array}$} & \multirow{2}{*}{$\begin{array}{c}\text { годишња } \\
\text { стопа, } \\
\text { м/м-12 }\end{array}$} & \multicolumn{2}{|c|}{$\begin{array}{c}\text { квартална } \\
\text { стопа }\end{array}$} & \\
\hline & & & & $q / q-1$ & $q / q-4$ & \\
\hline Сеп-17 & 129.0 & $-15.3 \%$ & $5.2 \%$ & \multirow{4}{*}{$21.7 \%$} & \multirow{4}{*}{$6.0 \%$} & \multirow{5}{*}{ IV 2017} \\
\hline Окт-17 & 109.4 & $-15.2 \%$ & $5.3 \%$ & & & \\
\hline Нов-17 & 100.3 & $-8.4 \%$ & $5.8 \%$ & & & \\
\hline Дец-17 & 115.8 & $15.5 \%$ & $6.8 \%$ & & & \\
\hline Јан-18 & 87.1 & $-24.8 \%$ & $5.7 \%$ & \multirow{3}{*}{$16.4 \%$} & \multirow{3}{*}{$4.9 \%$} & \\
\hline $\begin{array}{l}\text { Феб- } \\
18\end{array}$ & 87.3 & $0.3 \%$ & $4.8 \%$ & & & \multirow[t]{2}{*}{ I 2018} \\
\hline $\begin{array}{l}\text { Map- } \\
18\end{array}$ & 97.6 & $11.7 \%$ & $4.4 \%$ & & & \\
\hline Апр-18 & 103.1 & $5.7 \%$ & $6.4 \%$ & \multirow{4}{*}{$22.2 \%$} & \multirow{4}{*}{$6.0 \%$} & \multirow{4}{*}{ II 2018} \\
\hline $\begin{array}{l}\text { May- } \\
18\end{array}$ & 108.9 & $5.6 \%$ & $5.8 \%$ & & & \\
\hline Јун-18 & 120.3 & $10.5 \%$ & $5.8 \%$ & & & \\
\hline Јул-18 & 138.2 & $14.8 \%$ & $2.9 \%$ & & & \\
\hline Ауг-18 & 155.6 & $12.6 \%$ & $2.1 \%$ & \multirow[t]{3}{*}{$28.4 \%$} & \multirow[t]{3}{*}{$2.7 \%$} & \multirow[t]{3}{*}{ III 2018} \\
\hline Сеп-18 & 132.9 & $-14.6 \%$ & $3.0 \%$ & & & \\
\hline Оцт-18 & 115.7 & $-12.9 \%$ & $5.7 \%$ & & & \\
\hline Нов-18 & 105.9 & $-8.5 \%$ & $5.6 \%$ & \multirow{2}{*}{$19.6 \%$} & \multirow[t]{3}{*}{$5.4 \%$} & \multirow[t]{3}{*}{ IV 2018} \\
\hline Дец-18 & 121.7 & $15.0 \%$ & $5.1 \%$ & & & \\
\hline Јан-19 & 91.6 & $-24.7 \%$ & $5.1 \%$ & \multirow{3}{*}{$\begin{array}{c}- \\
15.9 \%\end{array}$} & & \\
\hline $\begin{array}{l}\text { Феб- } \\
19\end{array}$ & 93.0 & $1.6 \%$ & $6.5 \%$ & & \multirow[t]{2}{*}{$6.2 \%$} & \multirow[t]{2}{*}{ I 2019} \\
\hline $\begin{array}{l}\text { Map- } \\
19\end{array}$ & 104.2 & $12.0 \%$ & $6.8 \%$ & & & \\
\hline Апр-19 & 110.1 & $5.7 \%$ & $6.8 \%$ & \multirow{4}{*}{$22.3 \%$} & \multirow{4}{*}{$6.2 \%$} & \multirow{4}{*}{ II 2019} \\
\hline $\begin{array}{l}\text { May- } \\
19\end{array}$ & 115.2 & $4.6 \%$ & $5.8 \%$ & & & \\
\hline Јун-19 & 127.8 & $11.0 \%$ & $6.2 \%$ & & & \\
\hline Јул-19 & 147.3 & $15.3 \%$ & $6.6 \%$ & & & \\
\hline Ауг-19 & 165.5 & $12.3 \%$ & $6.4 \%$ & \multirow[t]{3}{*}{$28.0 \%$} & \multirow[t]{3}{*}{$5.9 \%$} & III 2019 \\
\hline Сеп-19 & 139.0 & $-16.0 \%$ & $4.6 \%$ & & & \\
\hline Оцт-19 & 123.1 & $-11.5 \%$ & $6.4 \%$ & & & \\
\hline Нов-19 & 111.8 & $-9.2 \%$ & $5.6 \%$ & $19.8 \%$ & $5.6 \%$ & IV 2019 \\
\hline Дец-19 & 127.5 & $14.1 \%$ & $4.8 \%$ & & & \\
\hline Јан-20 & 97.0 & $-24.0 \%$ & $5.9 \%$ & - & $1.6 \%$ & \\
\hline
\end{tabular}




\begin{tabular}{|c|c|c|c|c|c|c|}
\hline \multirow{3}{*}{ мјесец } & \multirow{3}{*}{$\begin{array}{c}\text { индекс } \\
\text { нивоа, } \\
2015=100\end{array}$} & \multicolumn{4}{|c|}{ стопа промета у трговини на мало, \% } & \multirow{3}{*}{ квартал } \\
\hline & & \multirow{2}{*}{$\begin{array}{c}\text { мјесечна } \\
\text { стопа, } \\
\text { м/м-1 }\end{array}$} & \multirow{2}{*}{$\begin{array}{c}\text { годишња } \\
\text { стопа, } \\
\text { м/м-12 }\end{array}$} & \multicolumn{2}{|c|}{$\begin{array}{c}\text { квартална } \\
\text { стопа }\end{array}$} & \\
\hline & & & & $q / q-1$ & $q / q-4$ & \\
\hline $\begin{array}{l}\text { Феб- } \\
20\end{array}$ & 101.7 & $4.9 \%$ & $9.4 \%$ & $19.0 \%$ & & I 2020 \\
\hline $\begin{array}{l}\text { Map- } \\
20\end{array}$ & 111.4 & $9.5 \%$ & $6.9 \%$ & & & \\
\hline Апр-20 & 81.3 & $-27.0 \%$ & $-26.2 \%$ & & & \\
\hline
\end{tabular}

Из представљених података евидентно је да је у односу на базну годину забиљежен драстичан пад трговине на мало (у текућим цијенама), тако да стопа промета у трговини на мало у процентима у априлу 2020. године износи - $27 \%$ (мјесечна стопа) и - 26.2\% (годишња стопа), док су у априлу 2019. године износиле $5,7 \%$ (мјесечна стопа) и $6.8 \%$ (годишња стопа). Сличан тренд је и кад је у питању пад укупне трговине на мало (у сталним цијенама).

Према актуелној класификацији дјелатности у Црној Гори, дјелатностима у трговини на мало се сматрају сљедеће дјелатности:

Групе дјелатности у трговини на мало

\begin{tabular}{|c|c|}
\hline Група & Дјелатност \\
\hline$\Gamma 47$ & Укупна трговина на мало \\
\hline$\Gamma 473$ & Трговина на мало моторним горивима \\
\hline$\Gamma 471$ & Трговина на мало у неспецијализованим продавницама \\
\hline$\Gamma 472$ & Трговина храном, пићем и дуваном \\
\hline Г47_НФ_ХЛТХ & $\begin{array}{l}\text { Трговина фармацеутским, медицинским, козметичким и } \\
\text { тоалетним препаратима }\end{array}$ \\
\hline Г47_НФ_ОТХ & Остала трговина на мало у специјализованим продавницама \\
\hline$\Gamma 47 \mathrm{X} 473$ & Укупна трговина на мало, без моторних горива \\
\hline
\end{tabular}

Како се ради о промету робе на коју се плаћа порез на додату вриједност, наступили су истовремени губици у предузећима која обављају дјелатност у трговини на мало и губитак државе по основу смањења ПДВ-а, који је држава требала да приходује. 


\section{Утицај пандемије на индексе цијена произвођача индустријских производа}

Цијене произвођача индустријских производа су у мају 2020. године у односу на април 2020. године веће за 0,2 \%, док су у периоду јануар-мај 2020. године и јануар-мај 2019. године у просјеку веће за 0,6\%.

Пораст цијена произвођача индустријски производа може се донекле објаснити баријерама које су уведене током периода пандемије код кључних добављача, те тежег пласирања производа и начина да се компензира утицај смањене тражње за овим производима. Са друге стране, пад цијена енергената, нпр. горива, давао је могућност компензовања ових цијена у оним областима у којима је гориво значајна ставка трошкова. Свакако, аутор овога рада сматра да нијесу постојали основани разлози за повећање ових цијена у условима пандемије, јер свако повећање цијена у индустријском сектору најчешће повлачи ланчано повећање цијена везаних производа. Свакако, за комплетан одговор било би потребно истражити однос понуде и тражње за овим производима у датом периоду.

\begin{tabular}{|l|l|l|l|l|l|}
\hline $\begin{array}{l}\text { Извор } \\
\text { Монстат }\end{array}$ & Назив & $\underline{\underline{\text { мај-20 }}}$ & $\underline{\underline{\text { мај-20 }}}$ & $\underline{\underline{\text { мај-20 }}}$ & јан-мај 2020 \\
пај) & апр.20 & ман-мај 2019 \\
\hline & УкУПнО & 99.7 & 100.2 & 100.3 & 100.6 \\
\hline
\end{tabular}

\section{Утицај пандемије на индексе цијена индустријских производа из увоза}

Индекси цијена индустријских производа из увоза представљају важне економске индикаторе који се могу користити као дефлатори временских серија, нарочито за потребе националних рачуна и као средство за усклађивање цијена при склапању различитих купопродајних уговора. ${ }^{10}$

\begin{tabular}{|c|c|c|c|c|c|}
\hline $\begin{array}{l}\text { Извор } \\
\text { Монстат }\end{array}$ & Назив & $\frac{\text { апр.20 }}{\varnothing 2019}$ & 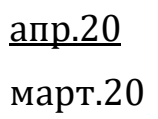 & $\frac{\text { апр.20 }}{\text { апр.19 }}$ & $\begin{array}{l}\text { јан-апр } 2020 . \\
\text { јан-апр } 2019 .\end{array}$ \\
\hline & УКУПНО & 97.5 & 98.1 & 97.5 & 101.2 \\
\hline
\end{tabular}

Цијене индустријских производа из увоза су у периоду јануар-април 2020. године и јануар-април 2019. године у просјеку веће за 1,2\%, при чему се највећи пораст у истом периоду односи на производњу прехрамбених производа који износи $13,4 \%$, што се лоше одразило на стандард грађана који су условима велике зависности Црне Горе у овој области у току пандемије куповали производе из увоза у количинама већим од реално потребних.

10 „Индекс увозних цијена“, Завод за статистику Црне Горе, доступно на: http://monstat.org/cg/page.php?id=28\&pageid=28 26/08/2020. 


\section{Утицај пандемије на индексе извозних цијена}

Статистика спољне трговине представља битан извор података за националне рачуне, биланс плаћања и краткорочне економске анализе. Она је веома значајна за праћење конкурентности земље у циљу успјешног вођења економских политика, припреми трговинских преговора и мониторинга, као и припрему трговинских споразума. На основу ње се утврђује: општа економска политика, развој трговинске политике, анализа тржишта за извознике и увознике, с циљем да се дефинише њихова комерцијална стратегија, утврђивање материјалних биланса за стратешке производе, с циљем да се контролише тржиште у области пољопривреде и енергије итд ${ }^{11}$.

\begin{tabular}{|l|l|l|l|l|l|}
\hline \multirow{2}{*}{$\begin{array}{l}\text { Извор } \\
\text { Монстат }\end{array}$} & Назив & $\underline{\text { апр.20 }}$ & $\underline{\text { апр.20 }}$ & $\underline{\text { апр.20 }}$ & јан-апр 20 \\
\cline { 3 - 6 } & $\varnothing 2019$ & март.20 & апр.19 & јан-апр 19 \\
\hline & УКУПнО & 94.6 & 98.4 & 93.1 & 97.3 \\
\hline
\end{tabular}

Извозне цијене су у периоду јануар- април 2020. године и јануар- април 2019. године у просјеку веће за 2,7\%, при чему се највећи пад цијена у истом периоду односи на производњу дуванских производа, који износи 5,6\%, и у производњи основних метала 4,3\%, што се лоше одражава на економију Црне Горе (пораст увозних цијена и пад извозних), посебно када се узме у обзир нпр. производња и продаја алуминијума и значај који има Комбинат алуминијума у Подгорици за економију Црне Горе.

Такође, као везана дјелатност - вађење руда метала је пала за 7,8\%, при чему је у овом удјелу најзначајнији боксит, који је основна сировина за производњу алуминијума.

Спољнотрговинска робна размјена је у периоду јануар-април 2020. године пала за $10 \%$ у односу на период јануар-април 2019. године.

\begin{tabular}{|c|c|c|c|c|c|c|}
\hline \multirow{3}{*}{$\begin{array}{l}\text { Спољнотрговинска } \\
\text { робна размјена } \\
\text { Извор } \\
\text { Монстат }\end{array}$} & \multicolumn{3}{|c|}{ Увоз } & \multicolumn{3}{|c|}{ Извоз } \\
\hline & $\begin{array}{c}\text { јан-апр } \\
2019 .\end{array}$ & $\begin{array}{c}\text { јан-апр } \\
2020 .\end{array}$ & $\begin{array}{c}\frac{\mathrm{jaн}-}{\mathrm{anp}} \\
\underline{2020 .} \\
\text { јан- } \\
\text { апр } \\
2019 .\end{array}$ & $\begin{array}{c}\text { јан-апр } \\
2019 .\end{array}$ & $\begin{array}{c}\text { јан-апр } \\
2020 .\end{array}$ & $\begin{array}{l}\text { јан-апр } 2020 . \\
\text { јан-апр } 2019 .\end{array}$ \\
\hline & $\begin{array}{c}\text { у хиљ. } \\
\text { ЕУР }\end{array}$ & $\begin{array}{c}\text { у хиљ. } \\
\text { ЕУР }\end{array}$ & Индекс & $\begin{array}{c}\text { у хиљ. } \\
\text { ЕУР }\end{array}$ & $\begin{array}{c}\text { у хиљ. } \\
\text { ЕУР }\end{array}$ & Индекс \\
\hline Укупно & 765,599 & 687,379 & 89.8 & 125,148 & 114,370 & 91.4 \\
\hline
\end{tabular}

11 „Spoljna trgovina“, Zavod za statistiku Crne Gore, dostupno na: http://monstat.org/cg/page.php?id=32\&pageid=32 26/08/2020. 
У Републику Србију је извезена роба вриједности 27,2 милиона еура, док је из Србије увезено 131 милион еура, што имплицира веома високу увозну зависност Црне Горе од Републике Србије, које НКТ није узимало у обзир током трајања „првог таласа“ пандемије.

\section{Утицај пандемије на индексе грађевинских активности}

Овај утицај је због значаја грађевинарства у свакој држави веома битан, јер даје директне податке о грађевинској производњи, ангажованим ресурсима и инвестицијама.

\begin{tabular}{|c|c|c|c|}
\hline Агрегати & $\frac{\text { QI } 2020}{\emptyset 2015}$ & $\begin{array}{l}\text { QI } 2020 \\
\text { QI } 2019\end{array}$ & $\begin{array}{l}\text { QI } 2020 \\
\text { QIV } 2019\end{array}$ \\
\hline $\begin{array}{l}\text { Вриједност извршених грађевинских } \\
\text { радова }\end{array}$ & 235.0 & 104.6 & 81.4 \\
\hline $\begin{array}{l}\text { Извршени ефективни часови рада } \\
\text { остварени на градилиштима }\end{array}$ & 166.5 & 107.6 & 97.5 \\
\hline
\end{tabular}

Евидентан је пад вриједности извршених грађевинских радова у износу од 18.6\% у односу на последња три мјесеца 2019. године, док су извршени ефективни часови рада пали за 2.5\%, што говори да су започети грађевински радови углавном настављени у вријеме пандемије, док је вриједност радова због актуелне ситуације на тржишту значајно смањена.

Ово потврђује и број издатих грађевинских дозвола и пријављених радова са

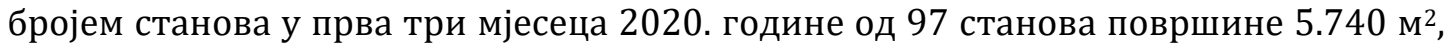
док је у истом периоду 2019. године евидентирано 523 стана са 29.152 м², а у посљедња три мјесеца 2019. године 550 станова површине 29.980 м2, што говори о опрезу инвеститора у односу на ток и ефекте пандемије.

Просјечна цијена квадратног метра стана у новоградњи у Црној Гори у прва три мјесеца 2020. године мања је за 8,2\% у односу на I квартал 2019. године, док је за $17,2 \%$ мања у односу на последња три мјесеца 2019. године, и то прије главног таласа пандемије.

\section{Утицај пандемије на индексе промета услуга према дјелатностима}

Овај утицај је од значаја за анализе привредног развоја на кратак рок, а приказан је у табели која слиједи.

Без обзира на кумулативни пораст цијена, значајан је пад цијена у дјелатностима које су од посебног значаја за Црну Гору, која је дугорочно оријентисана ка туризму. У односу на исти период 2019. године услуге смјештаја и исхране су смањене за 14\%, саобраћај и складиштење 79.9\% због смањеног промета роба и људи и нагомилавања залиха од стране грађана и других економских субјеката. 


\begin{tabular}{|c|c|c|c|}
\hline \multirow[t]{3}{*}{ НАЗИВ } & $\underline{\text { IQ } 2020}$ & IQ 2020 & IQ 2020 \\
\hline & $\varnothing 2015$ & IVQ 2019 & IQ 2019 \\
\hline & 94.6 & 73.5 & 100.4 \\
\hline $\begin{array}{l}\text { Трговина на велико и на мало моторним } \\
\text { возилима и мотоциклима и трговина на } \\
\text { велико }\end{array}$ & 101.6 & 78.6 & 108.2 \\
\hline Саобраћај и складиштење & 79.3 & 65.1 & 79.9 \\
\hline Услуге смјештаја и исхране & 71.8 & 61.5 & 86.0 \\
\hline Информисање и комуникације & 89.8 & 75.1 & 102.1 \\
\hline Стручне. научне и техничке дјелатности & 97.8 & 59.4 & 86.4 \\
\hline $\begin{array}{l}\text { Административне и помоћне услужне } \\
\text { дјелатности }\end{array}$ & 64.2 & 54.7 & 76.1 \\
\hline
\end{tabular}

Посебно је значајан утицај пандемије на дјелатност туризма (која дјелатност дјелује мултипликативно на економију Црне Горе), будући да се $75 \%$ укупне запослености у Црној Гори односи на туризам. Сем губитака насталих по привредне субјекте, везани су директни губици за државу због смањених фискалних прихода и ПДВ-а, пореза на добит, пореза и доприноса на смањене зараде и пореза и доприноса на лица која су због пандемијске кризе изгубила запослења. Исто тако, настали су губици и на локалним (општинским) нивоима за износе припадајућих општинских прихода из редовног пословања предузећа у туризму. Интензивирана и експанзивна државна фискална политика, као нпр. новоуведени порез на непокретности (земљиште) које се налази испод стамбеног објекта и служи редовној употреби објекта - које је у супротности са државним законодавством, додатно оптерећује грађане и директно утиче на њихов став и однос према мјерама које прописује држава. На овај начин рањивости државе на макронивоу преносе су на нивое домаћинстава.

Негативан утицај пандемије на туризам се осјетио и прије потврде пандемије у Црној Гори због тога што су земље из које су долазили туристи већ биле захваћене првим таласом пандемије, па су у прва три мјесеца 2020. године приходи из туристичке дјелатности смањени за $4,9 \%$.

У редовном економском 17. извјештају РЕР Свјетске банке ${ }^{12}$, објављеном 29. априла и 29. маја, наведен је илустративан примјер значаја туризма за економију Црне Горе у дијелу да ако се приходи од туризма смање за $1 / 3$, онда ће прогнозирани пад економије бити - 5,6\%; а ако се приходи преполове, економски

12 „The Economic and Social Impact of COVID-19“ Western Balkans Regular Economic Report, No. 17, 2020, available at:

http://documents.worldbank.org/curated/en/457181588085856454/pdf/The-Economicand-Social-Impact-of-COVID-19-The-Country-Notes.pdf 27/08/2020. 
пад ће бити до - 8,9\%. Ове пројекције пада прихода у туризму се одражавају и на потрошњу, инвестиције, извоз и увоз.

\section{КОМПЕНЗАТОРНЕ ЕКОНОМСКЕ АКТИВНОСТИ ДРЖАВЕ ТОКОМ ПАНДЕМИЈЕ}

Влада Црне Горе је током пандемије предузимала мјере усмјерене на ублажавање последица пандемије у дјелатностима које су оцијењене као угрожене односно најугроженије ${ }^{13}$ упркос нестабилнијем стању финансијског система у односу на исти период 2019. године. Ван тога током пандемије омогућена је подршка и медијима директним давањима и преко условно одложених или отписаних обавеза, као и субвенције за зараде лицима која су запослена у медијским кућама - директно и преко владиних тијела (Инвестиционо-развојни фонд Црне Горе и др.).

На сједници, одржаној 30. априла 2020. године, Влада Црне Горе је размотрила и усвојила Информацију о измјенама и допунама Програма пружања подршке привреди и запосленима, у циљу ублажавања негативних ефеката епидемије новог коронавируса ковид 19,14 који се састоји од следећих мјера субвенције у областима:

- субвенције за затворене дјелатности,

- субвенције за туристички сектор,

- субвенције за угрожене дјелатности,

- субвенције за ново запошљавање,

- субвенције за зараде запослених на плаћеном одсуству,

- субвенције за зараде запослених у карантину или изолацији.

Програмом је предвиђена подршка за неколико хиљада привредних субјеката са преко 100,000 запослених лица апликативним путем, са одређеним условима: задржавање запослених, редовност у измирењу пореских обавеза и др.

Оно што је од значаја јесте то да Влада Црне Горе ублажава негативне ефекте пандемије кроз очекивани ребаланс буџета и нова задуживања државе. Из саопштења министра финансија ${ }^{15}$ Владе ЦГ да државном буџету недостаје око

13 „Mjere na snazi“, Vlada Crne Gore, dostupno na: http://www.gov.me/naslovna/mjere_i_preporuke/ 28/08/2020.

14 Министарство економије, „Информација о измјенама и допунама Програма пружања подршке привреди и запосленима, у циљу ублажавања негативних ефеката епидемије новог корона вируса ковид 19“, Влада Црне Горе 30. април 2020, доступно на:

http://www.gov.me/naslovna/vijesti-iz-ministarstava/224167/Informacija-o-izmjenama-idopunama-Programa-pruzanja-podrske-privredi-i-zaposlenima-u-cilju-ublazavanjanegativnih-efekata-epide.html 28/08/2020.

15 „Ребаланс: Буџет ЦГ прилагођен новим околностима“, Центар за Маркетинг, 5. јун 2020, доступно на:

https://senat.me/rebalans-budzet-cg-prilagoden-novim-okolnostima/ 29/08/2020. 
878.000.000 еура, те да ће Влада ЦГ морати да се задужи за око још 500.000.000 еура, док ће јавни дуг износити $82 \%$ БДП-а (на крају 2019. године јавни дуг је износио 77.2\% БДП-а, односно 3,800,000,000 еура), што говори да ако Црна Гора не нађе повољно кредитирање из иностраних извора, може доћи у стање презадужености и немогућности да одговори сличним изазовима у будућности.

У редовном економском 17. извјештају РЕР Свјетске банке ${ }^{16}$, објављеном 29. априла и 29. маја, наведена су два сценарија кретања црногорске економије у условима пандемије, чије су пројекције урађене зависно од прихода у туризму:

\begin{tabular}{|l|c|c|}
\hline Економски параметар & $\begin{array}{c}\text { Кретање са 34\% пада } \\
\text { прихода у туризму }\end{array}$ & $\begin{array}{c}\text { Кретање са 50\% пада } \\
\text { прихода у туризму }\end{array}$ \\
\hline БДП & 5.6 & 8.9 \\
\hline Потрошња & 3.6 & 4.8 \\
\hline Инвестиције & 8.8 & 13.7 \\
\hline Извоз & 18.5 & 27.8 \\
\hline Увоз & 12.4 & 17.7 \\
\hline
\end{tabular}

То довољно говори о зависности црногорске економије од пандемијских стресова и њеној неприпремљености на изражене безбједносне ризике, с обзиром да је Министарство финансија Владе Црне Горе имало пројектовани реални раст БДП-а у 2020. години од $3,4 \%{ }^{17}$.

Може се закључити да ИМФ даје Црној Гори пројекције БДП-а са значајно горим трендом од земаља окружења: Албанија - 5\%, Босна и Херцеговина - 5\%, Србија $3 \%$, Сјеверна Македонија - 4\% и Хрватска - 9\%. Очигледно је да Хрватска и поред свих предности интеграције у ЕУ има велику зависност БДП-а од туризма, исто као и Црна Гора.

Сигурно је да би Црне Гора истицањем обавезног захтјева за увођењем система менаџмента континуитетом пословања (BCM) према државним органима и привредним субјектима дала један од могућих дјелимичних одговора на пандемијске и друге кризне изазове.

На основу података који су били доступни у јуну мјесецу пројектовани пад БДП-а од стране аутора исказан је на износ - 11,98, док је нпр. Европска банка за обнову и развој 1.10.2020. прогнозирала - 9\%, а Свјетска банка на - 12,40\%, што значи одступање у раду од свега $0,6 \%$.

16 „The Economic and Social Impact of COVID-19“ Western Balkans Regular Economic Report, No. 17,2020 , available at:

http://documents.worldbank.org/curated/en/457181588085856454/pdf/The-Economicand-Social-Impact-of-COVID-19-The-Country-Notes.pdf 27/08/2020.

17 „Пројекције Макроекономских показатеља за период 2019-2022 (2019)“, Министарство финансија Црне Горе, новембар 2019, Подгорица. 
Прогнозирани раст јавног дуга Црне Горе од стране Свјетске банке до краја 2020. године износи 93\% БДП-а, што довољно говори о катастрофалној економској ситуацији.

Сукобљавање економских и безбједносних интереса у Црној Гори огледало се најбоље кроз затварање граница за туристе из Србије и Русије, што је изазвало драстичан пад прихода у туризму (ова мјера, наводно уведена из здравствених разлога, јесте упитна са становишта економије и безбједности), као и грађанско незадовољство због Закона о слободи вјероисповијести или увјерења и правном положају вјерских заједница („Сл. лист ЦГ“, бр. 74/2019), које је под тензијом вирусне, политичко-економске и вјерске кризе пресудно утицало на исход избора.

\section{ЗАКЉУЧАК}

Економска наука, слично као и екологија, са којом има заједнички етимолошки коријен, увијек полази од претпоставке о општој повезаности свих појава, и то је најопштији оквир и граница унутар које се диференцирају и дефинишу облици економске повезаности, па је свако постављање неке хипотезе у ствари успостављање могуће повезаности међу појавама.

Економија Црне Горе није била спремна за пандемију ковида 19 из разлога што државни органи и привредни субјекти немају имплементиране системе којима се омогућава наставак пословања у условима изражених безбједносних ризика, што се огледа у ad hoc поступањима Националног координационог тијела за заразне болести (које је привремени орган), недовољној заштити угрожених и претежних привредних дјелатности, што је резултирало наглим падом: извоза, увоза, потрошње и инвестиција, а што је илустровано пројекцијама пада економске активности (БДП-а) од стране ММФ-а, који, нажалост, предвиђа виши пад макроекономских параметара у Црној Гори него код већине сусједних држава.

Немогућност квалитетног и безусловног субвенционирања, дисбаланс увоза и извоза, непрекидно задуживање државе и повећање износа јавног дуга на $82 \%$ БДП-а (за сада), неизвјесност исхода великих инфраструктурних пројеката који су у току - потврђују да се Црна Гора сама не може изборити са насталим последицама пандемије и да ће могући продужетак пандемије, односно неки нови економски стрес бити непремостива препрека за економију Црне Горе.

Сходно томе, треба ићи у сусрет безбједносним изазовима времена који могу имати несагледиве посљедице по друштво и економију, сагледавати их рационално и јачати капацитете државе за мултисекторску превенцију и одговор, као и регионалну сарадњу у том погледу. Дакле, досадашњи анализирани ефекти могу се посматрати тројако:

1. посматрањем макроекономских агрегата,

2. достигнутим облицима привредне сарадње са иностранством,

3. унутрашњим уређењем и друштвеним постигнућима. 
Збирном анализом сва три аспекта може се потврдити више него негативан утицај пандемије ковида 19 на економију Црне Горе, односно да је са њом потврђена полазна хипотеза (претпоставка) овога рада.

У безбједносној проблематици временско ограничење циљева је везано како за суштину, односно квалитет обављених активности, тако и за техничке термине постављених рокова. У принципу, за земље у транзицији изгубљено вријеме много више кошта него што је то случај са земљама у напреднијој фази развоја, па је тако и са Црном Гором. У сваком случају, мора се пронаћи повољан временски баланс између жеља и хтијења, са једне стране, и реалних могућности, са друге стране.

Гледано споља, уколико се трајање пандемије буде продужило, изгубиће се значајан дио страних инвестиција усљед изгубљеног повјерења инвеститора, што ће дугорочно нарушити имиџ Црне Горе, са свим негативним реперкусијама које то губљење носи са собом. Велики губици туристичке привреде одразиће се и на остале сегменте економије и људске дјелатности, а тензије у међусусједским односима такође могу имати значајне економске посљедице.

На унутрашњем плану, кашњење у спровођењу стратешких приоритета (као што је нпр. обавезно увођење система менаџмента континуитетом пословања) може довести до значајних конкурентских слабости и тиме поништавања компаративних предности економије Црне Горе у односу на друге земље са којима је могућа економска упоредба. Уколико се дуго нађе на размеђи два пута, могу се очекивати и значајне политичке импликације, анархичност у спровођењу директива и оправдан "ризик неинтеграције“ са развијеним економијама односно државама.

На основу спроведених анализа може се закључити да пандемије у потпуности и потенцијално дугорочно нарушавају односе између укупних користи и трошкова било које економије, па самим тим и економије Црне Горе, због чега треба благовремено и перманентно радити на препознавању овог савременог безбједносног изазова и имати спреман адекватан одговор на исти у смислу обучених кадрова и припремљених ресурса, и предвиђених модела кризног одговора и менаџмента, како би посљедице биле подношљивије у свим сферама, с посебним освртом на економију.

\section{ЛИТЕРАТУРА}

- „Индекс увозних цијена“, Завод за статистику Црне Горе, доступно на: http://monstat.org/cg/page.php?id=28\&pageid=28 26/08/2020.

- „Методолошко упутство: Статистика мјесечне трговине на мало (2012)“, Завод за статистику Црне Горе, Подгорица, јануар 2012, доступно на: https://www.monstat.org/userfiles/file/trgovina/2014/Metodologija\%20trgovine $\% 20$ na\%20malo.pdf

- „Пројекције макроекономских показатеља за период 2019-2022. године (2019)“, Министарство финансија Црне Горе, новембар 2019, Подгорица. 
- „Ребаланс: Буџет ЦГ прилагођен новим околностима“, Центар за маркетинг, 5. јун 2020, доступно на:https://senat.me/rebalans-budzet-cg-prilagodjen-novimokolnostima/ 29/08/2020.

- „Спољна трговина“, Завод за статистику Црне Горе, доступно на: http://монстат.орг/цг/паге.пхп?ид=32\&пагеид=32 26/08/2020.

- „The Economic and Social Impact of COVID-19“ Western Balkans Regular Economic Report, No. 17, 2020, available at:

- http://documents.worldbank.org/curated/en/457181588085856454/pdf/TheEconomic-and-Social-Impact-of-COVID-19-The-Country-Notes.pdf, 27/08/2020.

- „The pandemic is affecting elections around the world“, The Economist, 17th August 2020, available at https://www.economist.com/graphic-detail/2020/08/17/thepandemic-is-affecting-elections-around-the-world 20/08/2020.

- „The World Bank in Montenegro“, The World Bank, https://www.worldbank.org/en/country/montenegro, 20/08/2020

- „World Economic Outlook Update: A Crisis Like No Other, An Uncertain Recovery“, International Monetary Fund, June 2020, available at: https://www.imf.org/en/Publications/WEO/Issues/2020/06/24/WEOUpdateJune2 020, 23/08/2020.

- Baldwin, R., \& Weder di Mauro, B. Economics in the Time of COVID-19. Centre for Economic Policy Research, London, 2020.

- Danielli, S., Patria, R., Donnelly, P., Ashrafian, H. and Darzi, A. „Economic interventions to ameliorate the impact of COVID-19 on the economy and health: an international comparison. "Journal of Public Health, 13 July, 2020, pp.1-5.

- Fernandes, N. „Economic effects of coronavirus outbreak (COVID-19) on the world economy“" Available at SSRN 3557504: https://ssrn.com/abstract=3557504 or http: //dx.doi.org/10.2139/ssrn.3557504, 2020, 07/08/2020.

- Глушица, 3. Управљање инцидентима безбједности информација (засновано на ISO/IEC 27001). Институт за безбедност информација. Нови Сад, 2020.

- Гогић, J. Регионална економија, теорија и искуства у развоју. Никшић: ИТП Унирекс, Никшић, 1993.

- Johnson, B. "Our plan to rebuild: The UK Government's COVID-19 recovery strategy.", gov.uk, 24th July 2020. available at:

https://www.gov.uk/government/publications/our-plan-to-rebuild-the-ukgovernments-covid-19-recovery-strategy/our-plan-to-rebuild-the-uk-governmentscovid-19-recovery-strategy, 21/08/2020.

- Jordà, Ò., Singh, S. R., \& Taylor, A. M. Longer-run economic consequences of pandemics (No. w26934). National Bureau of Economic Research, Cambridge MA, 2020.

- Министарство економије, „Информација о измјенама и допунама Програма пружања подршке привреди и запосленима, у циљу ублажавања негативних ефеката епидемије новог коронавируса COVID-19“ Влада Црне Горе, 30. април 2020, доступно на: 
http://www.gov.me/naslovna/vijesti-iz-ministarstava/224167/Informacija-oizmjenama-i-dopunama-Programa-pruzanja-podrske-privredi-i-zaposlenima-u-ciljuublazavanja-negativnih-efekata-epide.html, 28/08/2020.

- Ralev, Radomir. „EC expects Montenegro's GDP to contract 5.9\% in 2020“, SeeNews, 6th May 2020, available at: https://seenews.com/news/ec-expects-montenegrosgdp-to-contract-59-in-2020-697818 23/08/2020.

- Словић, Д. Стресови у економији. Цонфинекс д.о.о. Београд, Београд, 2015.

\title{
IMPACT OF COVID-19 ON THE ECONOMY OF MONTENEGRO
}

\begin{abstract}
The analysis of the influence of the pandemic caused by COVID-19 virus which the World Health Organization (WHO) declared on March 11 2020 on the economy of Montenegro is of paramount importance in the conditions of growing security risks for which most countries in the world do not have an adequate defence strategy: preventive, active action and lessening of consequences of the pandemic. The economy of Montenegro, as most economies in the world, was not fully prepared for functioning in the conditions of a pandemic, and because of its consequences it cannot be prepared to face similar problem in the nearer future unless the social approach towards pandemic risks changes. In such context, anticipation of events based upon experience, whose consequences and a part of the solution are presented in this paper, represent a solid foundation for a deep consideration of this problem, their impact on the economy and possible mechanisms of protection - through continuous process of perfecting. Every economic system which wants to survive must have certain capabilities (qualities) for survival. One of the proposed qualities in this paper is the mandatory implementation of business continuity management system, greater participation of academic knowledge within governmental bodies, as well as the formation of a permanent national agency which would deal with prevention, active action and lessening the consequences of pandemic on the economy of Montenegro. Timely, bold and carefully thought measures for mitigating stressful situations can greatly limit the social and economic impact of the pandemic caused crisis.
\end{abstract}

Key words: economy, pandemic, COVID-19, risk, security 